\title{
O ENSINO DE CIÊNCIAS E O ACIRRAMENTO DA LUTA IDEOLÓGICA
}

\author{
Newton Duarte ${ }^{1}$
}

\begin{abstract}
Resumo
$\mathrm{O}$ acirramento da luta ideológica na contemporaneidade brasileira tem como uma de suas manifestações as ações, no campo da educação e para além dele, do obscurantismo beligerante contra a produção e difusão do conhecimento científico, da arte e do pensamento fillosófico. $\mathrm{O}$ objetivo dessas ações é o de que a escola não transmita o conhecimento científico, a não ser aquele que atenda aos interesses pragmáticos do mercado e aos ditames ideológicos da classe dominante. A acusação de doutrinação político-ideológica que a ultradireita dirige à escola e aos professores é apenas a aparência de um ataque de proporções bem maiores, pois se trata da tentativa de impedir o próprio ensino de ciências que se tornou campo de batalha ideológica. É uma luta para que o ensino dos conteúdos escolares não seja um obstáculo à disseminação do obscurantismo. Assim, quando os professores se posicionam em defesa do ensino, a todos, do conhecimento científico em suas formas mais ricas e desenvolvidas, estão se envolvendo nesse embate ideológico, independentemente do seu grau de consciência desse fato. Diante da perspectiva de aumento dos ataques obscurantistas à escola e das medidas de esvaziamento dos currículos escolares, os professores que trabalham com ensino de ciências serão levados cada vez mais a assumir explicitamente uma posição nessa luta ideológica.
\end{abstract}

Palavras-Chave: ensino de ciências; luta ideológica; pedagogia histórico-crítica

\section{Introdução}

Nos últimos dez anos temos presenciado no Brasil um acirramento da luta ideológica em todos os campos da prática social, da cultura e da vida humana. Esse acirramento vem ocorrendo principalmente em decorrência do avanço do obscurantismo beligerante. Além do obscurantismo ser uma posição hostil à produção e à difusão do conhecimento científico, do pensamento filosófico e da arte, ele também alimenta o ódio às pessoas que, de alguma forma, se mobilizam para gerar reflexões sobre a realidade social, a vida e o que está acontecendo no mundo. A escola que, na sociedade burguesa, sempre foi objeto de intensa disputa ideológica, torna-se objeto de polêmicas intensificadas por esse avanço do obscurantismo, como é o caso das tentativas de proibição da discussão de certos temas no interior das escolas, como a questão de gênero, que os conservadores religiosos rotularam como "ideologia de gênero" e tomaram como motivo para uma cruzada contra professores, currículos, livros didáticos etc. Ou então a questão da alegada “doutrinação política de esquerda" que seria realizada nas escolas e mais acentuadamente nas universidades públicas. Na verdade, é assim considerada qualquer

\footnotetext{
${ }^{1}$ Professor titular do Departamento de Psicologia da Educação, Faculdade de Ciências e Letras, UNESP, campus de Araraquara. E-mail: newton.duarte@unesp.br
} 
discussão que produza algum tipo de problematização da realidade social capitalista contemporânea, como é o caso, por exemplo, de discussões sobre aquecimento global, concentração de renda, etc. Tudo o que possa produzir algum questionamento em relação à eternidade do capitalismo e à visão neoliberal de sociedade é acusado de doutrinação esquerdista.

Não há o que se objetar se o argumento for o de que a escola não deve ser usada para aliciamento partidário embora, nesse caso, seja necessário assinalar que se trata de uma atitude hipócrita a de se acusar a esquerda de tentar usar o sistema escolar para fins partidários. Essa mesma extrema direita que diz defender uma escola neutra em nome da democracia, não vê qualquer problema em expressar publicamente seu saudosismo pela ditadura que aterrorizou nosso País de 1964 a 1985 e que obrigou as escolas a doutrinarem as crianças e os jovens na visão de que a ditadura não era ditadura, mas sim a salvação do Brasil da ameaça comunista.

Mas o que os atuais da escola não partidária pretendem, na verdade, não é lutar contra o aliciamento partidário no interior das escolas, mas sim difundir um clima de beligerância contra professores, currículos e materiais didáticos que estejam voltados para a socialização de conhecimentos que possam, ainda que indiretamente, contribuir para a compreensão das estruturas e dinâmicas sociais que geram os grandes problemas com os quais se depara a humanidade na atualidade.

Não apenas as ciências da sociedade, como a história e a geografia, que estão "na mira" (não é casual aqui o uso da metáfora armamentista) dos obscurantistas. As ciências da natureza, quando não se limitam aos conhecimentos pragmaticamente aplicados à produção de mercadorias, podem também se tornar objeto de acirradas polêmicas e candidatas à censura ideológica. Como, porém, seria possível ensinar de forma não alienada, na atualidade, as ciências da natureza sem se abordar a questão ambiental? E como abordar a questão ambiental de forma não alienada sem se analisar o modo como está organizada a produção material na sociedade contemporânea, ou seja, a produção de mercadorias? Como se discutir o desenvolvimento sustentável sem se colocar em questão a obsolescência programada das mercadorias? Em outras palavras, como ensinar ciências da natureza sem se discutir o que o capitalismo está gerando em termos de destruição das condições de vida em nosso planeta? Existe desenvolvimento sustentável sem a superação da lógica econômica comandada pelo capital?

Abordar o ensino de ciências frente ao acirramento da luta ideológica que enseja essas questões é propósito dessa exposição. 


\section{Desenvolvimento}

Ensinar de forma a promover o desvelamento daquilo que aliena a compreensão. Claro que essa linha de raciocínio é inaceitável para os obscurantistas que, de imediato, rejeitarão qualquer argumentação desse tipo, que será rotulada como discurso comunista e passará a ser atacada de forma inteiramente agressiva. Um dos argumentos usados para se condenar esse tipo de análise é o de que os professores devem se limitar a ensinar conteúdos científicos de forma neutra, sem pretender educar ou abordar questões de natureza ideológica ou ética. A escola ensina e a família educa. Quando se afirma que a família educa, especialmente no caso das crianças, está implícita a essa afirmação de que a educação dada pela família será orientada por princípios religiosos. Novamente é o caso de se apontar para a hipocrisia e a falta de memória dos obscurantistas que não viam qualquer problema que as escolas interferissem na formação moral das crianças na época da ditadura em que foi instituída a disciplina "educação moral e cívica" que consistia numa explícita doutrinação das novas gerações.

Teriam, então, os obscurantistas mudado de opinião e passado sinceramente a uma posição contrária à doutrinação nas escolas? Não, a verdade é que eles mudaram apenas de estratégia. Fingem atacar a doutrinação esquerdista, mas seu verdadeiro objetivo é o de que a escola seja espaço para uma única doutrina, a do neoliberalismo e sua naturalização do capitalismo como a única opção de sociedade. É por isso que dizem que a escola não deve educar, deve apenas ensinar gramática, matemática e ciências de forma neutra.

Nós, da pedagogia histórico-crítica, sempre defendemos que a escola deve ensinar as ciências, a arte e a filosofia. Mas não separamos o ensinar do educar e não confundimos a objetividade do conhecimento científico com neutralidade perante as escolhas éticas e políticas que a humanidade precisa fazer para enfrentar os grandes problemas da atualidade. Antonio Gramsci, nos seus Cadernos do Cárcere, já havia feito a crítica à separação entre educar e instruir (ensinar). Na época em que Gramsci escreveu sobre esse tema, a questão estava colocada de outra forma. Os educadores escolanovistas criticavam a escola tradicional, afirmando que ela só se limitava a ensinar o que estava nos currículos escolares e nos livros e não educava para a vida, não educava os indivíduos de forma mais ampla. Então Gramsci argumenta que as defesas do educar distinto do instruir apoiavam-se numa ideia equivocada, de que seria possível instruir, ou seja, ensinar os conteúdos escolares, sem se educar. O equívoco, segundo esse pensador, seria o de que só seria possível ensinar sem educar se os alunos pudessem assimilar os conhecimentos de forma absolutamente passiva. Gramsci considerava impossível essa total passividade dos alunos e acrescentava que havia aí uma contradição dos 
escolanovistas, já que eles próprios partiam, em suas críticas à escola tradicional, da afirmação de que a criança é um ser essencialmente ativo. Assim, Gramsci entendia que ao ensinar a escola também educa, mesmo quando os professores não tenham total consciência das implicações educativas do ensino.

Ele afirma que só seria possível ensinar sem educar se o aluno fosse pura passividade, o que é impossível e, ademais, acrescenta Gramsci, essa pura passividade é negada pelos próprios educadores que à época, defendiam que a escola devesse educar.

Apoiando-me nesta análise de Gramsci, entendo que não é possível ensinar na escola as ciências da natureza e da sociedade sem que, por meio desse ensino, estejamos trabalhando valores. O mesmo acontece com o ensino da arte e da filosofia. São valores que fazem parte da própria produção e difusão do conhecimento. Quando falo em valores, estou me referindo a visões de mundo o que implica, inevitavelmente, em conflitos ideológicos. Ou melhor, esses conflitos ideológicos podem ser camuflados, parcialmente evitados, mas, para isso, é necessário fatiar as ciências em objetos de estudo mais ou menos isolados, evadindo-se, dessa maneira, de discussões sobre a realidade como totalidade. Entretanto, ainda que a hiperespecialização da pesquisa científica e da própria formação dos cientistas na sociedade capitalista contemporânea seja favorecedora desse fechamento do ângulo de visão e do fatiamento do conhecimento científico, existe uma tendência na direção oposta, que é a da busca de respostas a perguntas fundamentais: O que é a realidade? O que é a sociedade? O que é a vida humana? Até que ponto o ser humano é sujeito dos rumos da vida e da história? No limite, esse tipo de questionamento produzido pela própria construção do conhecimento científico acaba por colidir com concepções de mundo pré-científicas, anticientíficas, que subordinam o mundo realmente existente a crenças em mundos transcendentes e em seres e forças místicas e misteriosas que comandariam o que acontece na realidade. O senso comum está repleto dessas crenças. As pessoas, por exemplo, afirmam que "ninguém morre antes da hora", o que significa que estaria previamente estabelecido qual seria o dia e a hora da morte de alguém. No extremo oposto ao desse fatalismo está outra crença, também presente no senso comum contemporâneo, de que a pessoa pode ser e fazer o que ela quiser, bastando, para tanto, que ela acredite em seus sonhos. O fatalismo fetichista e o voluntarismo subjetivista podem conviver tranquilamente no senso comum já que este, como mostrou Gramsci, é uma mistura de ideias de todo tipo sem que seja necessária a coerência entre elas.

Não estou afirmando que o ensino de ciências necessariamente levará alunos e professores a abandonarem suas crenças pessoais. Aceitar tal ideia implicaria desconsiderar as 
contradições existentes no próprio conhecimento científico e atribuir ao ensino escolar um poder exagerado de influência sobre as consciências. Mas, se por um lado, a pedagogia histórico-crítica deve evitar as ilusões iluministas sobre a natureza emancipadora das ciências e as visões não realistas do poder da educação sobre a formação das consciências, isso não significa que os educadores engajados com essa pedagogia devam abrir mão do compromisso político e pedagógico com a socialização do saber sistematizado. E, como explicou Gramsci, esse ensino escolar visa à superação de certas visões de mundo:

A escola, mediante o que ensina, luta contra o folclore, contra todas as sedimentações tradicionais de concepções do mundo, a fim de difundir uma concepção mais moderna, cujos elementos primitivos e fundamentais são dados pela aprendizagem da existência de leis naturais como algo objetivo e rebelde, às quais é preciso adaptar-se para dominá-las, bem como de leis civis e estatais que são produto de uma atividade humana, estabelecidas pelo homem e podem ser por ele modificadas visando a seu desenvolvimento coletivo. (GRAMSCI, 1982, p. 130)

Essa passagem de Gramsci faz referência às leis da natureza "como algo objetivo e rebelde", leis essas às quais os seres humanos devem se adaptar para poder dominá-las. Vou transpor essa análise de Gramsci para a terminologia de outro pensador marxista, György Lukács que analisou a dialética entre causalidade e teleologia na atividade humana de transformação da natureza, de produção dos meios necessários à satisfação das necessidades humanas. Para que o ser humano coloque as forças da natureza para agirem em função de determinados objetivos, é preciso conhecer e respeitar essas forças. Sem um conhecimento mínimo das causalidades envolvidas em determinados fenômenos naturais não é possível inserir nesses fenômenos as finalidades humanas, ou seja, não é possível fazer com que eles funcionem de maneira teleológica.

No que se refere às ciências da natureza, a objetividade do conhecimento produzido requer a eliminação de transposições antropomórficas do que é exclusivamente social para a esfera dos processos naturais. Uma dessas ilegítimas transposições antropomórficas é a tentativa de se explicar os processos causais existentes na natureza como se fossem resultado de finalidades estabelecidas por alguma forma de consciência, ou seja, como se fossem processos teleológicos. É o que faz, por exemplo, a chamada "teoria do design inteligente". Novamente fazendo referência ao senso comum, ele está repleto de exemplos de interpretação teleológica de processos que são causais. Um exemplo nesse sentido é o de se considerar que uma doença foi um castigo que uma pessoa recebeu por ter pensado, dito ou feito coisas moralmente reprováveis. 
Desde que o ser humano começou a dominar o fogo, a lascar a pedra, ele começou a inserir na realidade suas finalidades. As finalidades humanas se incorporaram à dinâmica de funcionamento da realidade. Só que esse é um campo específico, é o campo da ação humana, é o campo da atividade transformadora realizado pelos seres humanos, mas fora isso, nós temos um campo enorme da realidade no qual está ausente a finalidade. Está ausente a ação teleológica. A natureza não funciona assim. Vocês sabem melhor do que eu, vocês são estudiosos da ciência da natureza. A natureza funciona com base na causalidade, nos processos imanentes. Não é uma vontade, não é uma consciência, não é uma decisão que faz com que as coisas aconteçam. São processos imanentes que vão tendo consequências, desdobramentos da realidade. Até mesmo na sociedade isso acontece, porque muitas vezes nós agimos individual e coletivamente, visando determinados objetivos, mas as nossas ações desencadeiam uma série de processos sociais e objetivos que acabam gerando resultados que nós não prevíamos, que não esperávamos e até que não desejávamos, mas que acontecem independentemente do nosso querer.

Estamos falando, então, na objetividade do conhecimento científico. Objetividade essa que não pode ser empregada apenas num estudo parcelado da realidade como infelizmente muitos cientistas fazem. Muitos cientistas são objetivos, são rigorosos no seu método de investigação desde que ele se aplique a um pedacinho da realidade, mas não expandem esse rigor e essa objetividade para uma visão mais ampla da realidade, tanto da natureza quanto da sociedade. Já que estamos falando em objetividade, não sei se durante este evento vocês já discutiram essa questão e peço desculpas se eu estiver sendo repetitivo em relação a temas aqui já debatidos, mas gostaria de me deter um pouco sobre a diferença entre objetividade e neutralidade. Como já nos ensinou o professor Dermeval Saviani, em seu livro Pedagogia histórico-crítica: primeiras aproximações, objetividade não é sinônimo de neutralidade. Também Michael Löwy, em seu livro “As aventuras de Karl Marx contra o Barão de Munchhausen" discute as diferenças entre objetividade e neutralidade.

O conhecimento pode e deve ser objetivo. Podemos e devemos buscar a objetividade do nosso conhecimento, mas isso não implica neutralidade. Por exemplo, o conhecimento de que o Sol não gira em torno da Terra, nunca foi conhecimento neutro. Tanto não foi neutro que Giordano Bruno morreu na fogueira e Galileu Galilei só não foi para a fogueira porque teve que assinar uma humilhante abjuração. O estudo da evolução das espécies também nunca foi um conhecimento neutro, por mais que o próprio Darwin tenha assumido uma posição de conciliação com a visão religiosa. Muitos líderes religiosos até hoje não aceitam essa 
conciliação e conclamam seus fiéis a rejeitarem a evolução das espécies. Outro dia li na internet, na página de um pastor evangélico, ele alertando seus seguidores para os perigos do evolucionismo e argumentando que as pessoas que dizem acreditar no evolucionismo e também acreditar em Deus podem ser sinceras, mas sua crença religiosa é atenuada, pois, levado às últimas consequências, o evolucionismo cai no ateísmo. De certa maneira esse pastor percebe que o conhecimento científico, quando é levado às últimas consequências e passa a fundamentar uma visão de mundo, ele entra em colisão com visões que transpõem para a natureza processos que são específicos à realidade social. Em outras palavras, mesmo conhecimentos que não tocam diretamente em questões de natureza política e social, não deixam de ter impactos sobre nossos posicionamentos ideológicos, na medida em que eles causem transformações em nossa concepção de mundo.

Os conhecimentos impactarão de forma mais direta nossas ideias sobre o mundo se nos fizerem questionar o que é a vida humana, o que é o ser humano, o que é sociedade, o que nós estamos fazendo com a sociedade, o que a sociedade está fazendo com a natureza, etc.

Em suma, mesmo que os professores estejam ensinando conteúdos escolares que não façam referência direta a temas considerados polêmicos, eles não deixam de trabalhar com valores e ideias sobre a realidade humana e as relações entre sociedade e natureza.

Por exemplo, se o professor ensina o indivíduo a seguir um raciocínio matemático com rigor e com objetividade ou se ele ensina o indivíduo a ouvir e respeitar uma argumentação contrária à sua, observando as regras de consistência e coerência do pensamento, esse professor está ensinando que o pensamento mais desenvolvido tem regras que precisam ser aprendidas e empregadas. Pensar e argumentar de maneira coerente e consistente não faz de uma pessoa um revolucionário, mas é uma condição necessária, ainda que não suficiente, ao processo de superação das visões de mundo alienadas que prevalecem na cotidianidade contemporânea. É o caso, por exemplo, da formação de uma atitude de respeito pelo debate democrático de ideias em oposição à generalização do ambiente de ódio cultivado pelo obscurantismo.

Nós estamos falando, então, que os conteúdos escolares transmitem valores, o que não quer dizer, de forma alguma, que nós queremos professores dogmáticos e autoritários que obriguem os seus alunos a pensar do mesmo jeito que eles pensam. Até porque essa será uma tentativa fracassada. Nós professores não temos poder para obrigar nossos alunos a pensar como nós pensamos. O que nós professores podemos e devemos fazer é mostrarmos honestamente aos nossos alunos como nós pensamos. É claro, somos professores, nós ambicionamos sim, ensinar aos nossos alunos. Eu tenho a ambição, por exemplo, de convencer os meus alunos de 
que o que eu estou ensinando é correto. De que meus argumentos são bem fundamentados, mas quanto mais eu procurar explicar isso de maneira racional, de maneira rigorosa do ponto de vista do método, de maneira bem fundamentada, mais instrumentos eu disponibilizarei aos meus alunos para que eles possam discordar de mim.

No dia 12 de abril de 2018 foi realizada na Câmara dos Vereadores de Araraquara uma audiência pública para discussão sobre o projeto de lei "Escola sem Partido". Naquela ocasião fiz uma fala que aqui reproduzo por ter relação com o tema do acirramento da luta ideológica:

"Boa noite. Agradeço a esta casa pela oportunidade de me pronunciar sobre tão importante tema para o município de Araraquara. Venho pedir, muito respeitosamente, às senhoras vereadoras e aos senhores vereadores desta casa que não aprovem o projeto escola sem partido. Há trinta anos sou professor da UNESP, formo professores e, portanto, creio que falo também em nome de meus colegas, formadores de professores, de nossos alunos e exalunos que são professores. E por que peço a não aprovação desse projeto? Porque não é possível ensinar sem educar. Não é possível ensinarmos Matemática, Geografia, História, Arte, Educação Física, Ciências, Língua Portuguesa, enfim, os conteúdos escolares, sem que nós eduquemos nossos alunos, sem que nós transmitamos valores aos nossos alunos. Ensinar, e educar é cultivar nos nossos alunos o amor pela verdade, a paixão pelo conhecimento e é assumir um compromisso de formação integral, de desenvolvimento pleno de todos. Como é possível fazer isso se nós, educadores, professores, formos proibidos de nos posicionarmos sobre o mundo, sobre a vida, sobre a sociedade? Como nós podemos oferecer exemplos aos nossos alunos do que seja um cidadão engajado em construir um País livre, democrático, um País justo, se nós oferecermos como exemplo aos nossos alunos a omissão? O que esse projeto está propondo é que nós professores sejamos obrigados a nos omitirmos em relação aos grandes problemas do mundo, aos grandes problemas do Brasil, nos omitirmos em relação à vida, aos valores fundamentais que devem ser defendidos por cada um na sua vida. É claro que nenhum de nós é favorável a uma escola doutrinadora, nenhum de nós é favorável a que o aluno seja obrigado a aceitar esta ou aquela opinião ou posição. Nós queremos ensinar nossos alunos a se posicionarem, a pensarem criticamente sobre o mundo, e nós não poderemos fazer isso se nos calarmos e nos omitirmos, se não apresentarmos para os alunos o exemplo de quem tem algo a dizer sobre a sociedade. Pode ser que aquilo que digamos aos nossos alunos venha a ser contestado por eles e é bom que seja contestado, é bom que no futuro nossos alunos questionem aquilo que ensinamos a eles, mas eles não nos questionarão, não nos contestarão, se eles encontrarem na sala de aula um professor amordaçado, um professor que não diga a que ele 
veio, um professor que não se posicione em relação à sociedade e aos seus grandes problemas. É por isso que peço, senhoras vereadoras e senhores vereadores: permitam que as professoras e os professores de Araraquara continuem a educar as novas gerações, continuem a educar as crianças, os adolescentes e os jovens porque não é possível uma educação verdadeira se os professores estiverem amordaçados. Obrigado."2

O posicionamento do professor não ocorre apenas quando ele explicita uma posição sobre um assunto, mas também quando ele deixa de abordar determinados assuntos. É o caso, por exemplo, do tema da obsolescência programada das mercadorias. Quando o professor está trabalhando ciências da natureza, está trabalhando as relações entre sociedade e natureza e não toca no tema da obsolescência programada, isso é neutralidade? Não é. Isso é um posicionamento. Ele não toca nesse tema, porque ele considera que esse tema é perigoso. É perigoso, porque remete a questões ligadas às relações políticas e econômicas. Então, ele não está sendo neutro. Ele, deixando de discutir o tema, pode parecer que ele está adotando uma atitude de neutralidade, mas na verdade, ele está adotando uma atitude de concordância com um modo de funcionamento da sociedade, que deveria no mínimo, ser colocado em discussão. Quais são os argumentos a favor da obsolescência programada? Uma vez uma operária me colocou um argumento a favor e era um argumento consistente. Eu estava falando para ela desse problema e ela trabalhava em uma fábrica de celulares. E ela me disse: "mas professor, se fizerem um celular para durar bastante, eu perco o emprego". Ela tem razão. Ela tem um argumento dentro da lógica econômica da nossa sociedade. De fato, no final do ano, em uma rádio lá em Araraquara, tinha uma propaganda, uma exortação dizendo que as pessoas, no final do ano gostam de comprar presentes, vem o décimo terceiro e gastam o seu dinheirinho... e deveriam pensar “será que eu preciso mesmo comprar tudo isso que eu quero comprar?". Era uma exortação contra o consumismo. Mas paremos para pensar: e se todo mundo levasse a sério essa mensagem? E se ela fosse veiculada em todo o Brasil e a maioria da população aderisse à atitude de não consumir a não ser o que é essencial? A consequência seria, muito provavelmente, a de uma recessão econômica. Junto com a recessão, vem o desemprego e uma série de outros problemas. Então, quando eu falo que nós precisamos discutir a obsolescência programada, é discutir analisando isso dentro de toda uma dinâmica socioeconômica, porque, se não, vira quase uma exortação quase religiosa. Não por acaso a mensagem que ouvi na rádio foi na época do Natal. Ocorre que se não mudarmos a sociedade, não adianta combater o consumismo. Pode até ter um efeito positivo na vida da pessoa, se ela está se endividando

\footnotetext{
${ }^{2}$ Disponível em: https://www.youtube.com/watch?v=jo6fkHB57-s\&t=5s (Acesso: 15/09/2020)
} 
desnecessariamente, se está se alienando no puro consumir, mas não vai ter um efeito realmente significativo em termos de transformação social. É aquilo que a operária me argumentou, muito conscientemente, ela falou "professor, eu vou ficar sem emprego", porque nesta sociedade o consumismo é necessário para manter o nível de atividade econômica. A obsolescência programada é necessária para manter o nível de atividade econômica. Então, precisamos discutir a fundo essas questões. Não colocar isso em discussão, não é neutralidade. É se posicionar a favor da continuidade do capitalismo. Quem não discute esses temas é porque está se posicionando no sentido de deixar as coisas continuarem do jeito que estão.

\section{Conclusão}

Não ignoro a gravidade da situação que vivemos atualmente, de intimidação dos professores, de censura, de perseguição. Mas não podemos nos calar porque se fizermos isso será o mesmo que decretar o fim da nossa profissão e o fim da educação escolar. Não podemos nos deixar intimidar pelas atitudes beligerantes dos obscurantistas. Nossa obrigação é ensinar às novas gerações. As pessoas podem questionar o conteúdo que ensinamos? Claro que podem. Devem questionar, mas com fundamento, com propriedade, com argumento consistente e sólido. Então, se uma professora ou professor está ensinando evolução das espécies, esse ensino só poderá ser questionado a partir de argumentos científicos solidamente fundamentados. Não pode ser o argumento de que isso vai contra o que está escrito no livro religioso, da religião A, $\mathrm{B}$ ou C. A crítica àquilo que possa ir contra determinados preceitos religiosos pode ser feita na igreja ou nas redes sociais. É um direito legítimo numa sociedade democrática, mas nossa obrigação na escola é ensinar ciências, arte e filosofia, mesmo sabendo que seremos cada vez mais atacados por insistir em socializar esses conhecimentos. Não pensem que evitando este ou aquele assunto polêmico os obscurantistas nos deixarão em paz. Isso não acontecerá porque o objetivo deles é o de que a escola, na verdade, não transmita conhecimento, a não ser aquele que atenda aos interesses pragmáticos do mercado e aos ditames ideológicos da classe dominante. O objetivo deles é que a escola não lute contra a ignorância, que a escola não lute contra o obscurantismo. Então, não pensem que se cedermos um pouco, neste ou naquele tema, os obscurantistas deixarão que façamos nosso trabalho de ensinar ciências, arte e filosofia. Eles não deixarão. Eles só ficarão sossegados quando a escola, principalmente a escola destinada aos filhos da classe trabalhadora, estiver tão empobrecida, tão esvaziada que já não faça a mínima diferença o ir ou não ir à escola. Aí eles considerarão que a sua causa está ganha. 
Então, a minha mensagem aqui é de que ensinar ciências hoje é um trabalho na luta ideológica. Querendo ou não querendo. Sabendo ou não sabendo. Gostando ou não gostando. Quem ensina ciências está travando a luta ideológica. Então, é melhor nós sabermos o que estamos fazendo, nós nos posicionarmos e realizarmos essa luta ideológica de maneira bem consciente, porque os ataques serão cada vez mais intensos contra nós. Obrigado.

\section{Debate: ${ }^{3}$}

Questão 1: Bom, tentarei ser breve. Colocar três questões. Antes, só comentar quando você falou da fala da operária. Me lembrei de um comercial, não sei se todo mundo lembra, que é muito ideológico e mostra bastante disso, que é um comercial da Volkswagen de 2005, está no YouTube, é fácil de encontrar. Perfeito para sua vida. É exatamente nessa lógica. De começar a falar do perfeito. Mas espera aí, se esse mundo for tão perfeito assim, eu vou ficar sem emprego, mas como é que terei dinheiro para comprar meu Volkswagen? Aí implode tudo, a fumaça volta e tudo mais. É bem interessante, porque ele vai na lógica de fazer a crítica e depois defende essa... e tem uma outra crítica em cima disso que é o "necessário para sua vida", que é um estudante de graduação da época que faz a crítica do plano comercial, mas no final ele muda a história. Ele diz como seria interessante, sob outra perspectiva.

Bom, são três questões que eu queria colocar. Primeiro, se fosse possível caracterizar, o que seria esse movimento obscurantista do ponto de vista fascista, seriam alguns grupos religiosos? E o que explica esse fenômeno do ponto de vista de classe? A burguesia como um todo? Frações da burguesia? A que interessa à burguesia ou frações dela, esse obscurantismo?

Segundo ponto, quando você fala que não é revolucionário, mas é ético nós desenvolvermos o raciocínio lógico e aí é um pouco para você expor o que você coloca, como é que nós saímos dessa defensiva? Eu acho que é até além.

Em terceiro, é uma dúvida que eu tenho. Recentemente, estudando Gramsci com os companheiros. Essa posição de ódio do fascismo é contrária aos princípios liberais? Aí eu fiquei pensando, me parece que essa relação do fascismo com o liberalismo, na experiência italiana concreta, oscilou, desde antes até a tomada de poder pelo Mussolini, então, em determinado momento passa a ser contrário ao liberalismo, né. Em um primeiro momento, dialogava bastante

\footnotetext{
${ }^{3}$ Trata-se da transcrição do debate realizado na Mesa de encerramento do II Simpósio Materialismo Histórico Dialético e Pesquisa em Ensino de Ciências e Educação Ambiental, mediado pela Profa. Dra. Marília Freitas de Campos Tozoni-Reis.
} 
com o liberalismo, de repente, pensar historicamente, enfim, são essas questões que eu vou deixar para... obrigada.

Newton: Eu vou começar pela última questão. Você tem razão. Eu falei do liberalismo, mas o liberalismo, assim, nos autores clássicos, não necessariamente no posicionamento da burguesia, o posicionamento político-liberal. Você tem razão que o liberalismo, em muitos momentos se alinha, sim, a posições fascistas porque não interessa, concretamente. Eu estava me referindo aquele ensaio "Sobre a liberdade" do Stuart Mill, aquele ensaio não dá fundamento para as ações do MBL. Então, dá para criticar as ações do MBL citando Stuart Mill, não precisa ser Karl Marx. Eles têm um tipo de liberalismo que não encontra respaldo em alguns autores clássicos do liberalismo, mas uma coisa você tem razão. Concretamente, essas relações são mais complexas. E aí você pergunta, do obscurantismo, desse fenômeno e a questão de classe. Bom, vamos pensar, por exemplo, no Donald Trump. O Donald Trump é um exemplo de obscurantismo, não só pela truculência dele, pelo estilo dele... porque ele atrai um público... mesma coisa com o Bolsonaro. Ele cria um personagem para atrair um público. No caso, no Trump, ele defendeu explicitamente que não existe o efeito estufa, que não existe o aquecimento global. E aí tem cientista que ainda entra na discussão e fala "não, de fato, existem polêmicas, há quem diga que existe o efeito estufa, mas há quem diga que não existe”. Eu discuti com um professor que trabalha com ensino de ciências, polemizei com ele, porque fica nesse relativismo e aí eu falei: “mas afinal, os dinossauros, existiram ou não?”. Então, ele disse "por enquanto, o que se aceita é que existiram". O fato, porém, é que existem provas objetivas, científicas, da existência dos dinossauros. Esse tipo de relativismo entre os próprios cientistas e professores de ciências acaba inadvertidamente dando apoio a ideias obscurantistas como as defendidas por Donald Trump, que defende o lema America first, retira os Estados Unidos do acordo de Paris com o argumento de que primeiro é preciso pensar na economia americana para depois pensar nas questões ambientais. Ele está defendendo um setor da economia americana que apoiou a sua eleição. Ele está defendendo que não faz mal que poluamos mais, desde que aqueçamos a economia americana. Eu já havia escrito sobre isso, com esse tipo de raciocínio, em um texto meu "Educação e moral na sociedade capitalista em crise", que apresentei no Endipe no ano 2000. Naquele texto comentei que as pessoas iriam comemorar se ao final daquele ano o Brasil tivesse aumentado sua produção de automóveis. Qualquer governante de esquerda ou de direita comemoraria isso, pois teriam sido gerados mais empregos, arrecadados mais impostos, etc. Só que o aumento do número de carros circulando significa também aumento da poluição e aumento da contribuição para o aquecimento global, além de aumento do consumo de energia 
e matéria prima. Bom, então você me pergunta, o obscurantismo como fica em posição de classe? Do ponto de vista da consciência empírica de classe, a coisa é bem complicada. Donald Trump contou com votos de operários brancos, norte-americanos. Não foram só os extratos mais altos que votaram nele. Os trabalhadores votaram nele, com medo do desemprego. Então, do ponto de vista desta "consciência empírica" das classes, nós hoje em dia, vemos o obscurantismo penetrando nas várias classes sociais, mas se nós perguntarmos, historicamente, interessa a quem? Interessa à burguesia. Se a classe trabalhadora sabe disso ou não, é outra conversa, mas ele interessa à burguesia. O obscurantismo não interessa à emancipação da classe trabalhadora. É um fenômeno relacionado com o avanço da barbárie na sociedade capitalista. Barbárie está cada vez mais intensa em todos os campos da vida social. Então, defender a continuidade dessa sociedade é muito difícil do ponto de vista racional. Eu acho que para defender a continuidade dessa sociedade, você tem que defender o sentimento do medo. O que é a guerra ao terror desde o tempo do Bush? O Bush desencadeou aquela guerra e com isso ele conseguiu colocar os Estados Unidos como sendo defensores do mundo contra o terror, contra o horror e contra um monte de coisa. E ele saiu bombardeando mundo afora. Então, o que as pessoas estão defendendo aqui no Brasil é que tem que usar arma. As pessoas vão votar no Bolsonaro, porque acreditam que tem que andar armado mesmo. É o medo. As pessoas estão agindo de acordo com o medo. O medo é irracional. O medo é obscurantista. O medo é um sentimento muito poderoso.

A outra pergunta... quando nós saímos da defensiva. Eu vou falar de nós professores. Nós professores saímos da defensiva se nos posicionarmos radicalmente no sentido de que nossa tarefa é transmitir conhecimento, doa a quem doer. Ninguém vai nos impedir de transmitir o conhecimento. Nós temos legitimidade para isso. Hoje perguntaram para mim "mas então, professor, você está admitindo que a escola pode influenciar o aluno? ”. Não, eu estou dizendo que a escola deve influenciar o aluno. Eu não estou admitindo que ela pode, como se fosse para termos o cuidado de não influenciarmos, estou dizendo que ela deve influenciar o aluno. Afinal, a criança ou o adolescente, o jovem ou o adulto, estão submetidos a muitas influências. Ninguém vive em uma bolha de plástico ideológica, protegido de outras influências. Nós estamos expostos a todo tipo de influência. Se é criança, está exposta à mídia, está exposta à internet, está exposta a todo tipo de influência da família, da propaganda, da igreja etc. Por que a escola também não pode influenciar? Que instituição tão perigosa é essa, a escola, que é a única que não tem o direito de influenciar a criança? Então, vamos radicalizar. A nossa tarefa é educar as novas gerações. 
Questão 2: Meu nome é Antônio, eu sou professor da rede, comunista. Eu queria perguntar ao professor sobre esse obscurantismo, como ele chega na educação e na formação dos professores e, assim, o que me parece é que ele chega travestido de conhecimento acadêmico e até progressista e eu vejo na autoajuda. Eu percebo que na educação que a autoajuda, por exemplo, com o Cortella, estão ganhando um espaço na educação absurdo e eu vejo isso como um obscurantismo, como uma decadência ideológica mesmo, como um obscurantismo travestido de uma coisa progressista. Eu gostaria que o senhor falasse um pouquinho da particularidade desse liberalismo que existe no Brasil. Porque, em relação à doutrinação, eu vejo que essa doutrinação está no currículo, que é uma doutrinação neoliberal, que eu vejo aqui, uma concepção de indivíduo neoliberal. Então, isso não deixa de ser uma doutrinação ideológica, mas uma doutrinação ideológica liberal. Eu gostaria que o senhor comentasse um pouco sobre isso, mas principalmente sobre essa questão do obscurantismo, que me incomoda bastante.

Newton: Tem um livro que foi uma tese de doutorado, que um orientando meu defendeu, o nome dele é João Henrique Rossler e o título do livro é "Sedução e alienação do discurso construtivista", naquele livro ele analisa estratégias que são empregadas com os professores para sedução de professores. Esses discursos de autoajuda que você mencionou utilizam largamente dessas estratégias de sedução. Então, mobilizam-se, os sentimentos, as emoções das pessoas, no sentido de se encantarem com alguma coisa, com determinado tipo de argumento, de visão e aí as pessoas aderem a algum autor, a alguma linha pedagógica, ideia, etc., não porque estejam convencidas, porque estudaram, porque se aprofundaram naquela discussão e optaram, mas porque se deixaram levar emocionalmente. Então, isso é uma forma sim de colocar de lado a capacidade de análise crítica, racional, fundamentada e em seu lugar, fazer com que as pessoas se mobilizem, porque simpatizam ou antipatizam com uma determinada fala, com determinados argumentos. Então, as pessoas aderem ou não, por que gostam ou não gostam, da mesma forma que gostam ou não gostam de uma comida, de uma roupa etc. Sim, o obscurantismo ele pode chegar a nós de diferentes maneiras. Tem o obscurantismo mais agressivo que é dessa direita sem partido, das agressões, dos xingamentos, que quer pôr todo mundo na cadeia ou simplesmente executar as pessoas nas ruas com as armas de fogo, mas também tem aquele que vem falando macio, com falas que seduzem, mas que também podem conduzir na mesma direção. Agora, a questão do liberalismo, de fato, é claro que não sou ingênuo. Eu sei que o mais difundido na sociedade é o tipo de visão que apresenta o capitalismo como a única forma possível de organização social. Nesse sentido, é claro que o 
liberalismo é hegemônico e se ele é hegemônico é claro que ele está nos currículos, nos materiais didáticos e assim por diante. Mesmo assim, os ideólogos militantes em defesa desse capitalismo que nada mais tem a oferecer à humanidade, se preocupam que o ensino de ciências, de artes e de filosofia possa oferecer algum risco no sentido de tirar as pessoas, ainda que momentânea e parcialmente, do anestesiamento produzido pela alienação cotidiana. Tenho argumentado em meus escritos e minhas palestras e aulas, já algum tempo, que a burguesia havia percebido antes da esquerda que a escola não é uma aliada natural da classe dominante. A esquerda passou muito tempo afirmando que os conteúdos escolares são burgueses, que a escola é alienante, que é inculcação da ideologia dominante etc. A direita, por sua vez, há bastante tempo vem acusando as escolas públicas e as universidades públicas de serem dominadas pela ideologia comunista. Espera aí, é estranho né. A esquerda fala que é coisa da burguesia, a direita fala que é coisa de comunista. Pois é. Eu acho que a direita está mais certa, porque, de fato, um sistema que socialize o conhecimento nas suas formas mais desenvolvidas, isso tem impacto na visão de mundo. Isso não interessa à lógica da burguesia e à ideologia burguesa. Michael Löwy, no livro que mencionei, “As aventuras de Karl Marx contra o Barão de Munchhausen", cita Gramsci para dizer que a verdade é revolucionária. Difundir a verdade é um ato revolucionário. Portanto, tem razão a direita ao temer a escola, ao dizer que ela é perigosa. E é mesmo.

Professora Marília: eu queria agradecer a presença do professor Newton, mais uma vez, de forma brilhante, como sempre, mais uma vez, brilhantemente como todas as vezes que eu o escuto e o leio, converso, traz grandes contribuições para pensar o ensino de ciências e a educação ambiental, que é o que nos mobiliza nesse momento e essa perspectiva, não ultrapassada, do materialismo histórico-dialético, que nós estamos tentando avançar no sentido de formar pesquisadores e professores que se apropriem de forma um pouco mais aprofundada mesmo de um instrumento metodológico para pensar os processos educativos que nos dizem respeito, do ensino de ciência e da educação ambiental. Acho que nós tivemos várias contribuições desde o início, hoje para isso. Da primeira e segunda mesa, encerrando a terceira mesa com o relato do que os nossos grupos vêm produzindo dentro dessa perspectiva e fechamos agora com uma contribuição privilegiada, porque eu acho que o tema da ideologia é fundamental. Eu penso que só o materialismo histórico-dialético pode clarear essa articulação profunda que nós temos em uma sociedade sob o modo capitalista da produção. Uma articulação profunda entre a educação e a ideologia. Eu acho que desvendar isso para os pesquisadores e para nós pesquisadores que estamos pensando o ensino de ciências e a educação 
ambiental, é fundamental. Mais uma vez eu queria agradecer a contribuição para esse que foi o primeiro simpósio dos dois grupos de pesquisas, que reuniu os dois grupos de pesquisa e assim como nos fóruns, nós temos um fórum de educação ambiental que também vem se reunindo, que começou com dois grupos de pesquisa que hoje já tem uns dez grupos de pesquisa. A educação ambiental marxista no Brasil, que éramos dois ou três e agora já somos mais de dez grupos de pesquisa e que nós consigamos avançar como nós já estamos avançando na educação ambiental, pensando nessa articulação entre o ensino de ciências e a educação ambiental dentro do materialismo histórico-dialético. Então, obrigada a todos, e obrigada particularmente à comissão organizadora.

\section{Referências}

GRAMSCI, A. Os intelectuais e a organização da cultura. 4. ed. Rio de Janeiro: Civilização Brasileira, 1982. 